International Journal of Health Sciences
Available online at www.sciencescholar.us
Vol. 6 No. 1, April 2022, pages: $214-233$
e-ISSN: 2550-696X, p-ISSN: $2550-6978$
https://doi.org/10.53730/ijhs.v6n1.3828

\title{
Systematic and Educational Influences of Civil Society on Public Administration Communications Organization in Quarantine Restriction COVID-19 Condition
}

\begin{abstract}
CrossMark
Natalia Dragomyretska ${ }^{a}$, Iryna Matvieienko ${ }^{b}$, Dmytro Samofalov $^{c}$

Manuscript submitted: 10 September 2021, Manuscript revised: 9 December 2021, Accepted for publication: 8 January 2022

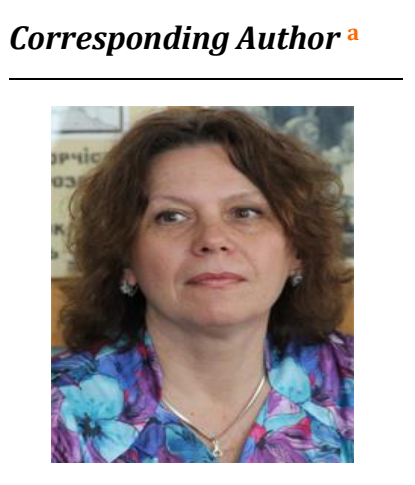

Keywords

civil society;

COVID-19 condition;

educational influence;

educational institution;

electronic services;

health care;

local communities;

\section{Abstract}

The purpose of the study is an analysis of the systemic influences of civil society on the public administration communications. The study focuses on interaction with the residents of the respective united territorial communities, and on the participation of public organizations in the communication processes of territorial communities - to improve the quality of services to the population in quarantine measures. The peculiarities and the main aspects of digital interaction with the residents of the territorial community and effective coverage of the government's activities with digital tools are identified. The practices of holding general meetings, public hearings, budget implementation, use of electronic petitions, appeals, work of advisory bodies and selforganization bodies, organization of access to collegial bodies in conditions of quarantine restrictions due to the COVID-19 epidemic were considered. It has proposed to make more active use of e-democracy tools to interact with community members on the basis of transparency and openness of government. It was proved that the participation of representatives of civil society institutions in local self-government advisory bodies significantly increases the capacity of local authorities to communicate and ensureselforganization, representation, realization and protection of interests and rights of citizens.
\end{abstract}

\section{Contents}

Abstract

1 Introduction.

2 Materials and Methods

a Odessa Regional Institute for Public Administration, Odessa, Ukraine

b Odessa Regional Institute for Public Administration, Odessa, Ukraine

c National Health Service of Ukraine, Odesa, Ukraine 


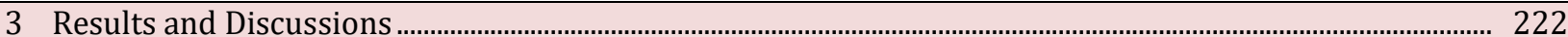

3.1 Analysis of tools of public management communications of civil society and government.................. 222

3.2 Methodical recommendations on the use of communication tools in quarantine....................................... 2226

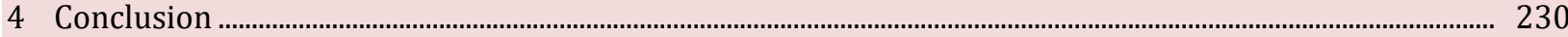

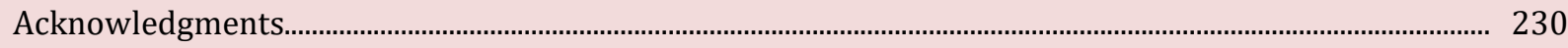

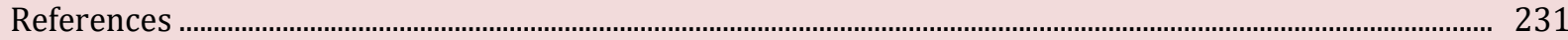

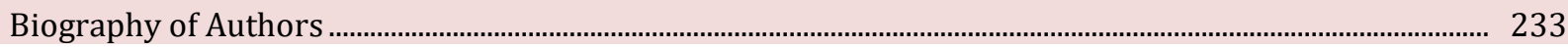

\section{Introduction}

In the conditions of the territorial-administrative reform of Ukraine, active measures on the transformation of public service of Ukraine into service, communications acquire a special role. The strengthening of local selfgovernment raises the issue of community participation through the tools of local democracy. A sign of the sustainability of civil society in the functioning of organizations (institutions) of civil society, through which citizens and social groups ensure self-organization, representation, implementation, and protection of interests and rights (Vasilescu et al., 2010). The quality of the democracy and the community participation depends on the introduction by the local council of appropriate tools: general meetings, public hearings, participation budgets, local initiatives, e-petitions, and so on. Under the influence of the digital transformation, the latest communicative structures, processes, and forms have formed, which provide a qualitative change in the socio-communicative environment (Bozeman \& Straussman, 1990; Bondarenko, et al., 2021). Effective public administration is impossible without building in the field of public administration a proper system of both internal and external communications, an effective system of information exchange in each team, community, and the state as a whole, and effective human resource management (Savvas \& Bassiliades, 2009; Szczepaniuk et al., 2020). Business communication becomes a multifaceted process of establishing and developing contacts between people. This is not only the exchange of information but also the perception and understanding of all participants in the communicative process of a single line of communicative interaction. In such conditions, information transparency of public administration, timely informing the public becomes an effective tool for ensuring openness and transparency of public authorities (Savinova et al., 2021). Communicative interaction becomes a component of the democratic decision-making process and a prerequisite for the realization of the right of citizens to participate in public administration (Bhuiyan, 2011). For subjects of the public administration, this means the creation of appropriate tools to ensure access to information, the introduction of innovative methods for its submission, ensuring the freedom to receive and disseminate information, the opportunity to express their views (Nataliia et al., 2021; Wahyuni et al., 2022). Thus, the role of communications in the system of public administration is growing. The communications have been considered as a factor that provides:

- The possibility of establishing a permanent relationship between public authorities and citizens;

- The need to focus the activities of public authorities on the needs of society;

- The tools for the formation of public opinion as a prerequisite for the prevention and solution of socially important problems.

In this sense, the process of informing the public is seen as a kind of public communication aimed at achieving the goals and implementation of state functions, taking into account the needs and interests of society. Civil society is becoming an essential building block of development and national cohesion (Rasmussen et al., 2014; Rodchenko et al., 2019). Moreover, for countries affected by conflict, civil society has a particularly important role (Maloney, 2015; Kuznetsov et al., 2020). The civil society includes non-governmental organizations, including schools and universities, advocacy groups, professional associations, churches, and cultural institutions (business has sometimes been referred to as civil society). Civil society organizations play different roles:

- Become an important source of information for both citizens and the government (Fraussen \& Halpin, 2018);

Dragomyretska, N., Matvieienko, I., \& Samofalov, D. (2022). Systematic and educational influences of civil society on public administration communications organization in quarantine restriction COVID-19 condition. International Journal of Health Sciences, 6(1), 214-233. https://doi.org/10.53730/ijhs.v6n1.3828 
- Monitor public policy and actions, bring the state to justice (Marquez, 2016);

- Advocate and propose alternative policies for government, the private sector, and other institutions (Ainsworth \& Sened, 1993);

- Provide services, especially to the poor and needy;

- Protect the rights of citizens and work to change and maintain social norms and behavior.

Communications play a catalytic role (for example, the media) in influencing relationships and management processes. In this case, communication has considered vital to ensure:

- connection of states with society;

- promoting the inclusiveness of political systems;

- giving voice to poor and marginalized groups, and ensuring citizen participation and social responsibility.

Given the current issues of troubled states, the interest of the scientific community and donors in how communication can contribute to state-building by improving relations between citizens and promoting the construction of social contracts in conflict-affected states has increased. The purpose of the study is an analysis of the systemic influences of civil society on public administration communications (De Nicola et al., 2016; Lozano \& Vallés, 2007). The object of research is the forms of direct participation of civil society and citizens in local self-government, including through electronic services and their impact on public administration communications (Pieterson et al., 2007; Lindgren \& Jansson, 2013). The subject of the study is the presence of certain forms of public administration communication and citizen participation in local selfgovernment in communities, as well as the systemic influences of civil society on the reality of their use during crises, including quarantine. This study highlights the following issues:

- Identify the features and main aspects of the current state and systemic prerequisites for strengthening the communicative interaction of public authorities and civil society institutions in Ukraine;

- Identify areas for strengthening the impact of civil communication on the democratization of Ukraine's public administration system.

\section{Literary review}

The development of civil society has been associated with the ability of citizens to influence government decision-making, as well as to exercise the right to participate in the local self-government at the level of territorial communities. The National Strategy for the Civil Society Development for 2016-2020 was approved by the Decree of the President of Ukraine on February 26, 2016, №68 / 2016. The priorities are as follows:

- To the creation of favorable conditions for the formation and institutional development of civil society organizations;

- To ensure effective procedures for public participation in the formation and implementation of state and regional policy, addressing issues of local importance;

- To stimulate the participation of civil society organizations in the socio-economic development of Ukraine;

- To the creation of favorable conditions for intersectoral cooperation.

Civil society has represented by public organizations, which are characterized by the appropriate organizational capacity, ie the potential of the organization to achieve its mission and goals (Eisinger, 2002; Kovalenko, 2013). Such organizations (institutions) include public associations, religious organizations, charitable organizations, creative and professional unions and their associations, employers' organizations and their associations, associations, bodies of self-organization of the population, etc. In this case, the organizational potential characterizes the organizational features that allow NGOs to effectively generate, process, and transmit information (Daugbjerg, et al., 2018; Khomutenko, et al., 2019). To achieve their goals, organizations need to go beyond free organizational mechanisms such as networks and become more 
formalized structures with autonomy, hierarchical structures, and certain levels of specialization (Schmitter \& Streeck, 1999; Klochan, et al. 2021). The conceptualization of organizational capacity indicates the idea of professionalization, in particular, the availability of experience for the formation of technical knowledge and centralized management structures that apply a technocratic and scientific approach to organizational support and communications (Maloney, 2015; Dykha, et al., 2020; Widana et al., 2021).

The organizational potential of public organizations has been based on organizational features: autonomy (Verhoest et al., 2004; Hubanova et al., 2021), centralization (Christensen et al., 2016; Cherchyk et al., 2019), and functional differentiation (Pugh et al., 1968; Bondarenko et al., 2021). In the social space, civil communications have been understood as a system of communication networks (channels) that provide:

- Connection of individuals with non-profit, non-governmental, public organizations;

- The relationship between the structures of civil society (non-profit, non-governmental, public, etc.);

- Connection of civil society as a whole (as a set of non-profit, non-governmental, public organizations) with other components of the social system;

- The possibility of participation of individuals and civil society structures in the development, discussion, and decision-making on an economic, a political, a social, and other issues, ie in the field of public policy (Manin, 1987; Mufidah et al., 2021).

Improving the communication environment contributes to the continuous change of organizational forms of governance. Communication, as a social phenomenon, reflects the one-line orientation of the informational influence of any subject on the object, with feedback or reaction of the object to the influence has not provided. The classical model of communication has presented in Figure 1.

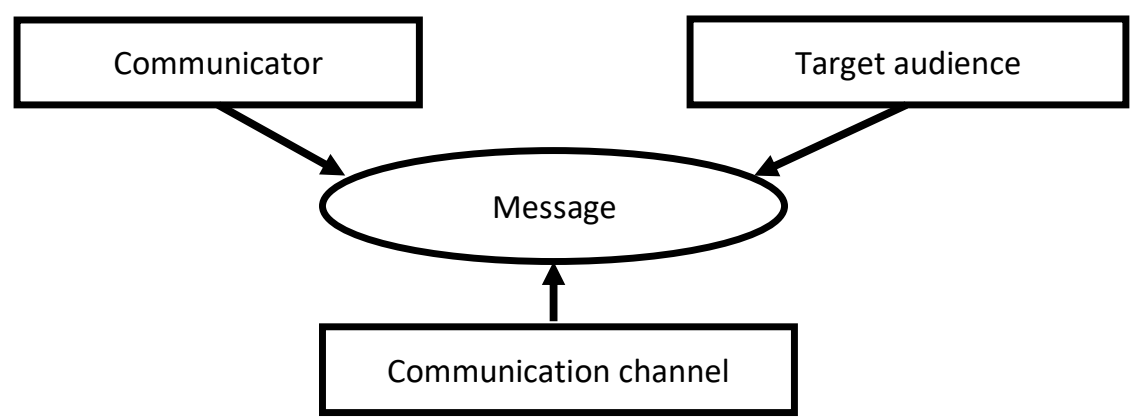

Figure 1. Model of the communication process

There are different data models of communication, based on the different tasks facing the researcher. If you group the factors that shape the communication process, specifying its form and content, you can see the following parameters: the communicator factor - sets the tasks and goals that it pursues and that affect this process; the target audience factor - determines the interests of the recipient; the communication channel factor - sets the standards of this channel. This set of knowledge allows the communicator to achieve specific goals. Figure 2 shows dotted lines additional connections that make the control system more dynamic, susceptible to new changes.

Dragomyretska, N., Matvieienko, I., \& Samofalov, D. (2022). Systematic and educational influences of civil society on public administration communications organization in quarantine restriction COVID-19 condition. International Journal of Health Sciences, 6(1), 214-233. https://doi.org/10.53730/ijhs.v6n1.3828 


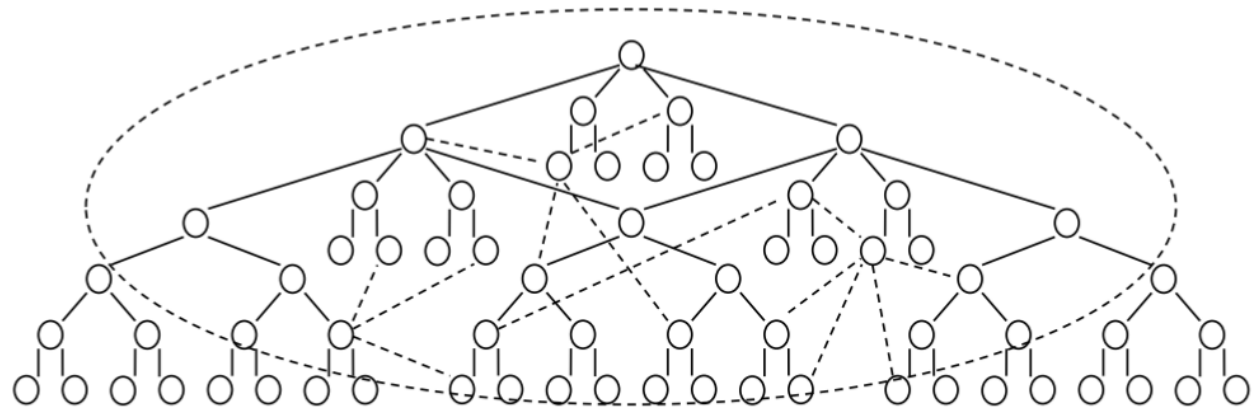

Figure 2. Management system in the public sector with elements of non-hierarchical connections and communications

The further development of forms of management is due to the latest technologies in the field of communications: instant exchange of electronic information, audio and video conferences, organization of Internet communities, etc. The introduction of Internet technologies changes the management structure, which has been expressed by the transition from hierarchical forms to the network (Fig. 3).

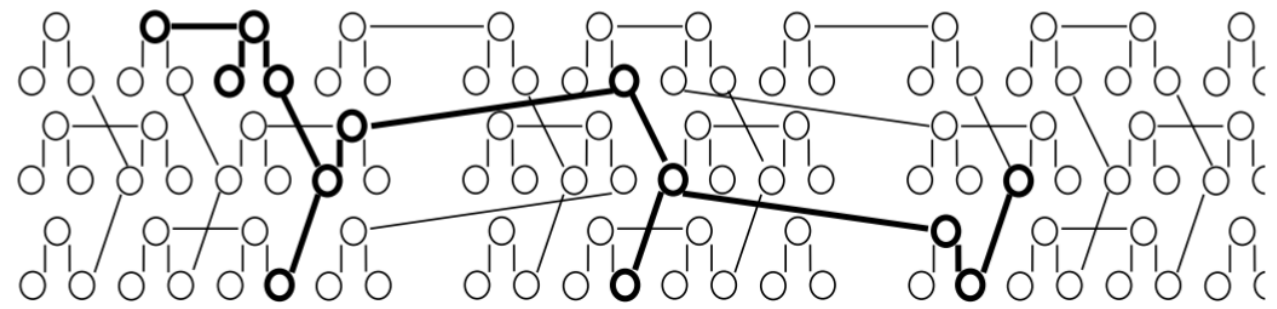

Figure 3. The system of network management and interaction of public organizations under the influence of Internet technologies

Figure 3 shows a network management model in which it is possible to implement any hierarchy (one of these possible hierarchies as shown in the figure by a bold line). Moreover, the network model allows you to instantly rebuild and change the forms of management of society. Currently, such models have been implemented in the network structure of interaction of public organizations. Network communications can significantly expand the scope of examination of management decisions. Network forms of management are especially relevant in the implementation of project activities in the public administration sphere. Communicative connections and information exchange take place between all components of the social system (Figure 4).

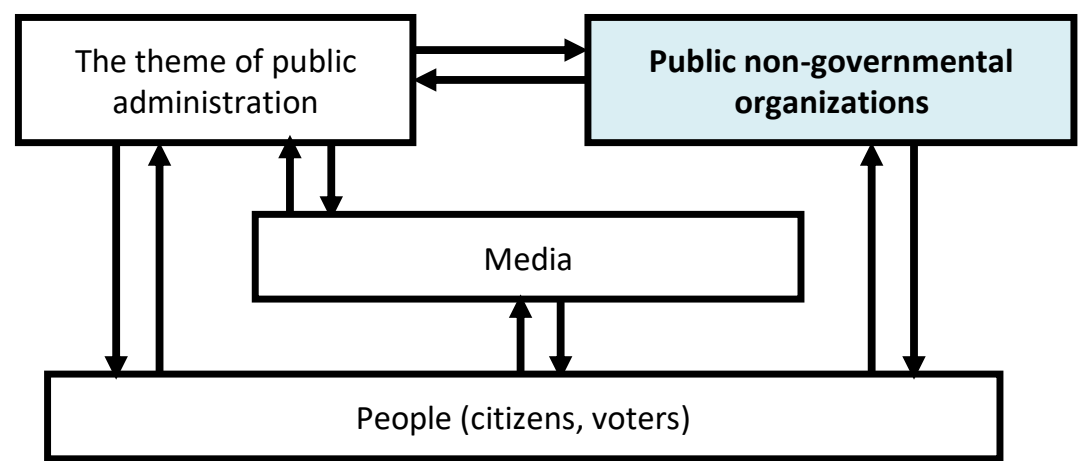

Figure 4. Communicative connections between components of the social system 
The types of public administration communications by levels of interaction between government and civil society are presented in Table 1. Communicative communication has been carried out in the form of communication, during which there is an exchange of messages. In general, many studies conclude that there is a need for a better understanding of the circumstances in which communication, and in particular the media, can be a powerful force for positive development change (Albers et al., 2016; Sudomyr et al., 2020), and why in other cases it may be a more malicious force capable of blocking reforms for the poor, generating political violence and supporting an undemocratic political system (Berkhout et al., 2017; Korepanov et al., 2020).

The proponents of communication also argue that the strategic use of political communication tools and methodologies can influence the attitudes, opinions, and behaviors of key stakeholders and provide the political will needed to successfully implement reforms on the ground (Rajwani et al., 2015). Thus, civil society organizations play an important role as both implementing partners and the target audience. Although the role of communication in supporting democratic development and stimulating economic growth is increasingly recognized in international policy statements, in practice communication remains a relatively low priority on the so-called "good governance" agenda.

Table 1

The types of public management communications by level interaction between government and civil society

\begin{tabular}{|c|c|c|}
\hline $\begin{array}{l}\text { Levels } \\
\text { interaction }\end{array}$ & Essence & Components \\
\hline Informing & $\begin{array}{l}\text { Open and free access to the necessary, } \\
\text { complete, and timely information is } \\
\text { important to ensure a transparent and } \\
\text { accountable policy. } \\
\text { The information should be available to } \\
\text { citizens, as well as to public organizations } \\
\text { for them to effectively perform the function } \\
\text { of a controller. }\end{array}$ & $\begin{array}{l}\text { - The decision-making processes by local } \\
\text { authorities; } \\
\text { - The policy development documents; } \\
\text { - The documents related to draft decisions; } \\
\text { - The documents and transcripts of } \\
\text { consultations, other public events; } \\
\text { - The constant coverage of information on } \\
\text { the websites of the involved entities }\end{array}$ \\
\hline Consultancy & $\begin{array}{l}\text { The extensive discussion by representatives } \\
\text { of local authorities and civil society } \\
\text { organizations of various ways to solve a } \\
\text { specific policy problem. } \\
\text { It has expected that during the } \\
\text { consultations, local authorities will gather } \\
\text { and summarize opinions and positions, } \\
\text { which may be very different. } \\
\text { The subject of consultations is often } \\
\text { determined by the authorities rather than } \\
\text { the public }\end{array}$ & $\begin{array}{l}\text { - Conducting public hearings and round } \\
\text { tables with the participation of decision- } \\
\text { makers to identify topical issues and collect } \\
\text { proposals; } \\
\text { - Conducting expert seminars and meetings } \\
\text { to prepare expert recommendations for } \\
\text { solving the problem; } \\
\text { - Holding sessions or committee meetings } \\
\text { with the opportunity for the public to } \\
\text { express their views; } \\
\text { - Organizing public events, conferences, } \\
\text { forums, and seminars to inform and discuss } \\
\text { the results of policy implementation with } \\
\text { the participation of civil society } \\
\text { organizations and citizens. }\end{array}$ \\
\hline Dialogue & $\begin{array}{l}\text { Bilateral communication between the } \\
\text { authorities, on the one hand, and civil } \\
\text { society organizations and citizens, on the } \\
\text { other. Dialogue is a common way for } \\
\text { authorities and civil society organizations } \\
\text { to discuss issues. Therefore, issues for } \\
\text { discussion can be determined by both }\end{array}$ & $\begin{array}{l}\text { Holding regular meetings to exchange } \\
\text { views, as well as specialized meetings on } \\
\text { specific issues; } \\
\text { - Providing feedback on the meetings held by } \\
\text { both the authorities and civil society } \\
\text { organizations. }\end{array}$ \\
\hline
\end{tabular}

Dragomyretska, N., Matvieienko, I., \& Samofalov, D. (2022). Systematic and educational influences of civil society on public administration communications organization in quarantine restriction COVID-19 condition. International Journal of Health Sciences, 6(1), 214-233. https://doi.org/10.53730/ijhs.v6n1.3828 
parties (dialogue-cooperation).

Partnership Provides for the division of responsibilities for the policy-making process. Relevant for the development or implementation of a specific policy or project where civil society organizations can be involved in a specific implementation
- The involvement of civil society organizations at the stage of policy development or implementation of the decision;

- The civil society organizations should have the right to remain independent - to organize campaigns related to the relevant policy issue;

- The ability to make joint decisions (for example, when forming local budgets).

Some attribute this to the lack of strong evidence to demonstrate the impact of communication on management. Others argue that communication support - which typically includes the development of an independent media sector, improved access to information, and the strategic use of media and political communication to influence behavior and social change - is a legitimate area of donor funding (Rasmussen et al., 2014).

The available research on the role of communication in governance was divided between different disciplines with often conflicting priorities (including political science, communication, media research, and development research). At the same time, there is a lack of practical guidance available to policymakers on understanding and using communication in governance reform.

\section{Materials and Methods}

To achieve the goal of this study, the general and special methods were used:

- Analysis and synthesis - for a detailed description of the selected object of study;

- Generalization - to reveal the theoretical and methodological foundations of the mechanisms of influence of the civil society on public administration communications;

- The comparative method and systematization - to study the regulatory and legal support of communicative interaction of the civil society with the public administration;

- The system method - when revealing the conceptual foundations of the influence of the civil society on public administration communications;

- A logical, a dialectical, the method of generalization, a complex and a systemic approaches - to improve an individual definition;

- The statistical analysis, the comparison, and the generalization - to study the peculiarities of the formation of communicative interaction of civil society with public administration bodies;

- The graphic - for a visual representation of the results;

- The abstract logical method - for theoretical generalization and formulation of conclusions and proposals.

The methodological basis of the study is the scientific works of domestic and foreign authors and official publications of international organizations. The information and the empirical basis of the study consisted of normative documents of state and regional authorities, statistical and sociological data, materials published in periodicals, and the Internet. This study contains an overview of issues related to civil society, reflects the key trends in the development of civil society organizations in Ukraine.

The paper highlights various aspects of the implementation of key priorities for the development of civil society, which are set out in the National Strategy for the Promotion of Civil Society in Ukraine in 2016-2020. Regarding the creation of favorable conditions for intersectoral cooperation, examples have been given that testify to the cooperation between public authorities and representatives of charitable organizations and public associations. 
The survey data show that cooperation between the civil society organizations remains at a high level, including information exchange, joint activities, and projects. The study proves that an important factor for the development and strengthening of democracy in Ukraine is the further formation of conditions for solving the problems of the civil society organizations that depend on the state, in particular in the legal sphere, the development of participatory democracy, and effective cooperation mechanisms in the future. The communication environment is the material that makes up the management system in organizations. The criteria for analysis were:

- A target audience;

- A key message;

- A channel, a means, tools of communication.

The study involves the use of tools:

- Analytical study of local regulations governing the procedures of public participation in local government. In particular, the tools of public administration communications and norms that create barriers for residents to use the tools of local democracy, as well as participation procedures in terms of their adaptability to quarantine requirements in the context of the spread of COVID-19 were studied;

- Analysis of the practices of using public management communication tools for the participation of civil society in crisis conditions, in particular during quarantine. The practices of holding general meetings, public hearings, budget implementation, use of electronic petitions, appeals, work of advisory bodies and self-organization bodies, organization of access to collegial bodies in conditions of quarantine restrictions due to the COVID-19 epidemic were studied;

- Analysis of communication tools to inform the population about the activities of local governments, including in the direction of counteracting COVID-19;

- The official community websites were examined to highlight the opportunities for residents to participate in local self-government under quarantine restrictions;

- The level of public confidence in social institutions, including public organizations. In writing the article, data from a study conducted by the Razumkov Centre's sociological service were used.

To identify the confidence of the population in social institutions, including public organizations, data from the "Communication Modeling Center" were used, which conducted a survey. The survey was conducted for the period July-August 2020 by the method of the List based samples of high coverage populations based on the formed wide group of respondents.

The cluster sample is representative of the adult population (18 years and older) of Ukraine in terms of "region". The sample was 2118 questionnaires, the sampling error with a probability of 0.95 does not exceed $2.2 \%$. The study covered 27 united territorial communities in nine regions of Ukraine (Figure 5).

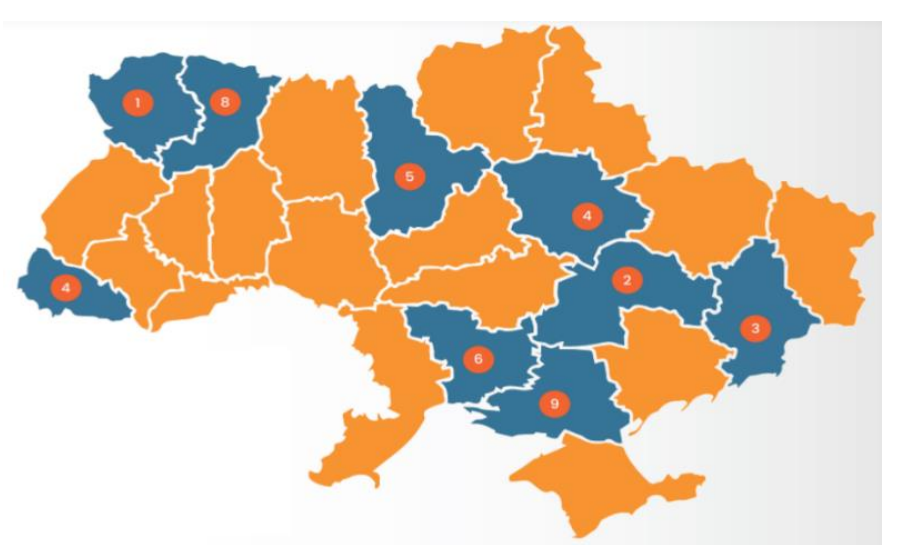

Figure 5. The territorial coverage of the study, Ukraine, July-September 2020

Dragomyretska, N., Matvieienko, I., \& Samofalov, D. (2022). Systematic and educational influences of civil society on public administration communications organization in quarantine restriction COVID-19 condition. International Journal of Health Sciences, 6(1), 214-233. https://doi.org/10.53730/ijhs.v6n1.3828 
The theoretical basis of the study is the classification of e-government when e-government has considered in terms of three components:

- the internal system of work;

- the interface of interaction with the "client";

- the method of communication with other organizations.

The theoretical foundations of the study are these:

- The level of trust of citizens directly depends on the strategy and forms of communication of the public organization;

- The division of responsibilities between the state and the non-profit sector;

- Hansmann's theory of trust: business and public organizations.

The study focuses on the second component - interaction with the residents of the respective united territorial communities, and the third - the participation of public organizations in the organization of communication processes of local communities - to improve the quality of services to the population in quarantine (Leslie et al., 2007).

\section{Results and Discussions}

\subsection{Analysis of tools of public management communications of civil society and government}

The number of formed public associations, other public formations, print media is a reflection of the state of formation of civil society. In total, the number of officially registered public organizations in Ukraine, according to the State Statistics Service, has increased over the past ten years by more than 85000 . During this time, 77252 public organizations with the local status have been legalized by local justice bodies (Figure 6).

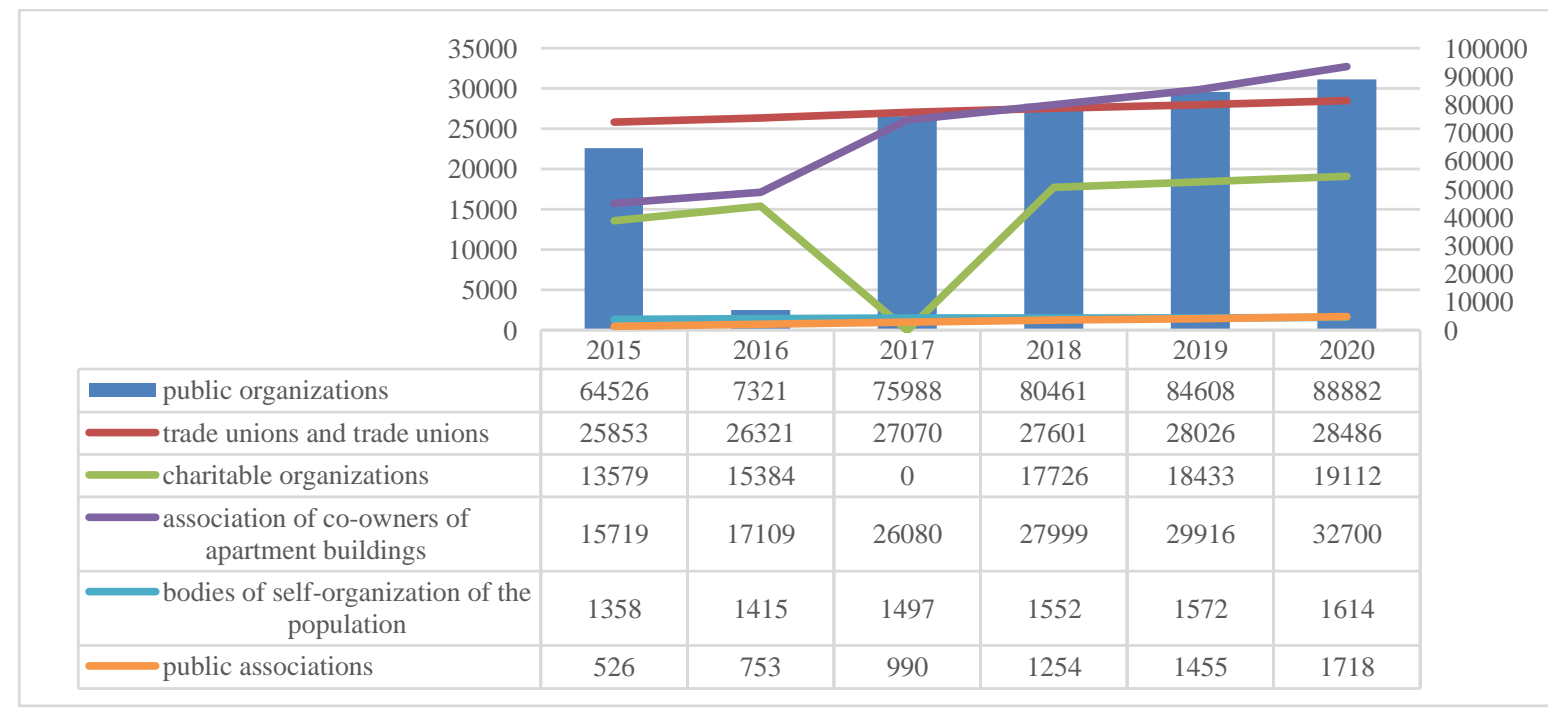

Figure 6. Public organizations, according to the State Statistics Service of Ukraine, 2015-2020

However, the growth in the number of public organizations has little effect on increasing the level of involvement of citizens in their activities. Since 2013, the membership of citizens in various public associations is $15-17 \%$. Also, increasing the number of public organizations is not the same as increasing their influence on the decision-making process. If in $201824 \%$ of respondents believed that public organizations can promote reforms, in 2019 only $9 \%$ of respondents indicated such ability. This trend has been observed against the background of a general decline in public confidence in the authorities. According to research, the 
activities of public organizations meet the key needs of society. According to the results of the online survey "Capacity assessment civil society organizations under COVID-19, conducted by the Coalition Resuscitation Reform Package, most public organizations in Ukraine (97\%) continued to operate in the context of the coronavirus pandemic, with almost half (45.6\%) actively involved in countermeasures COVID-19.

In recent years, the leaders of trust among social institutions have been the army, the church, and public organizations (What do Ukrainians expect from public organizations, 2020). At the same time, Ukrainians positively perceive public organizations - 8 out of 10 points, and donor structures:

- $86 \%$ support that public organizations are learning from the experience of reforming Western countries;

- $80 \%$ like that talented young people can study and earn thanks to donor grants;

- $70 \%$ believe that receiving foreign funding by public organizations does not mean that they are not working in the interests of Ukraine;

- $67 \%$ do not agree that people from public organizations who went to work in government are unprofessional.

In general, a public organization in the minds of citizens is no longer a hobby or just a civic position, it is a job, and modern, promising, and competent. At the same time, a purposeful information campaign against the public sector already leads to the existence of a persistent negative attitude towards public organizations on certain issues:

- $40 \%$ of respondents believe that the activities of foreign donors should be controlled and blocked;

- $40 \%$ believe that foreigners receive data through public organizations to establish control over attractive areas of Ukraine's economy;

- $45 \%$ share the opinion that public organizations and foreign structures jointly use grant funds. And this makes it impossible for the public sector to broadcast their ideas, not those of donors.

The perception map of the "world of public organizations and donors" shows (Figure 7) that the public sector and donor structures are perceived by people through three parameters: money (who finances); a vector of integration (where we aspire); an activity (how the desire has achieved).

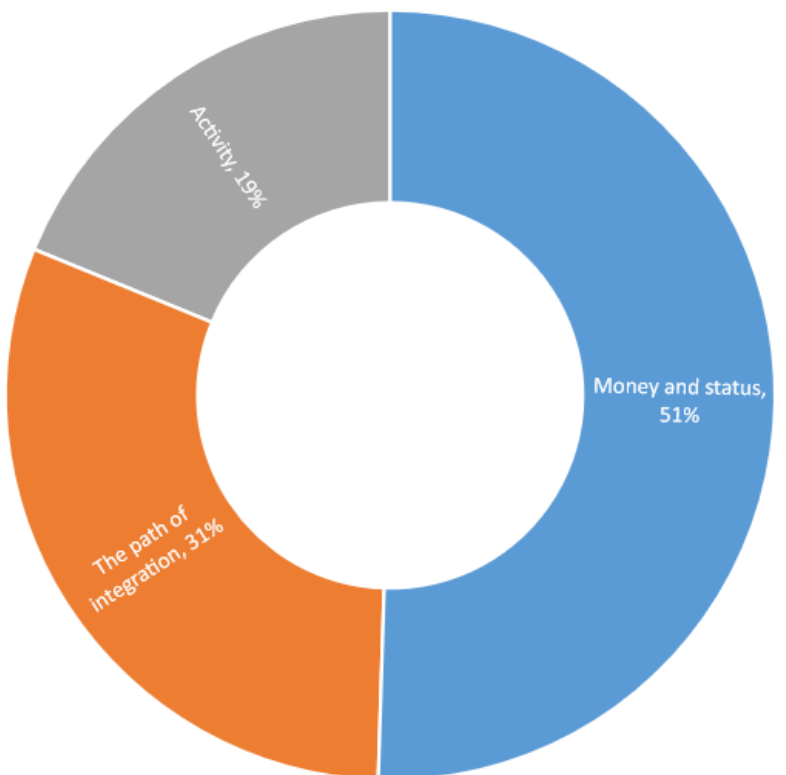

Figure 7. Map of perception of the "world of public organizations and donors"

Dragomyretska, N., Matvieienko, I., \& Samofalov, D. (2022). Systematic and educational influences of civil society on public administration communications organization in quarantine restriction COVID-19 condition. International Journal of Health Sciences, 6(1), 214-233. https://doi.org/10.53730/ijhs.v6n1.3828 
Currently, $75 \%$ of citizens say that discussing the role of the public sector, organizations, donor structures, as well as the "reality or far-fetchedness" of external influence is relevant. The main danger is in the formation of paradoxes that can block further discussion, or completely marginalize the topic under discussion. According to sociological research the Razumkov Center (2021), among state and public institutions, trust is most often expressed in the Armed Forces of Ukraine (70\%), the volunteer organizations (65\%), the Church (64\%), the State Emergency Service (63\%), the State Border Guard Service (60\%), and the National Guard of Ukraine (56\%), the Mayors (villages, villages) where the respondent lives (56\%), the volunteer battalions (55\%), the public organizations (53\%), the city councils (villages, villages) where the respondent lives 51\%) (Table 2). In recent years, associations of various formats and practices of public self-organization have been successfully operating in Ukraine.

The following work on the network principle: all-Ukrainian public associations in the agricultural sector; all-Ukrainian public associations in the field of work with internally displaced persons; associations (unions) of organizations participating in hostilities in eastern Ukraine. Along with public associations that have been operating in Ukraine for many years (Ukrainian Union of Industrialists and Entrepreneurs of Ukraine, AllUkrainian Association of Small and Medium Business Entrepreneurs "FORTETSYA" and others), the Assembly of Public Organizations of Small and Medium Business, the Association farmers and landowners of Ukraine", "Agrarian Union of Ukraine", "Union of Ukrainian Peasants", etc. Entrepreneurs 'associations, farmers' and landowners 'associations (farmers' associations), etc. operate at the regional level.

Table 2

Do you trust social institutions?

\begin{tabular}{|c|c|c|c|c|c|c|}
\hline & $\begin{array}{l}\text { I do not trust } \\
\text { at all }\end{array}$ & $\begin{array}{l}\text { Rather, } \\
\text { I do not trust }\end{array}$ & $\begin{array}{l}\text { I rather } \\
\text { trust }\end{array}$ & $\begin{array}{l}\text { I completely } \\
\text { trust }\end{array}$ & $\begin{array}{l}\text { Difficult to } \\
\text { answer }\end{array}$ & $\begin{array}{l}\text { Balance of } \\
\text { trust and } \\
\text { distrust }\end{array}$ \\
\hline The President of Ukraine & 29.8 & 31.7 & 25.6 & 6.8 & 6.1 & -29.1 \\
\hline The Verkhovna Rada of & & & & & & \\
\hline Ukraine & 34.1 & 43.4 & 15.1 & 2.0 & 5.4 & -60.4 \\
\hline The Government of Ukraine & 35.4 & 40.4 & 16.5 & 1.8 & 5.9 & -57.5 \\
\hline The State apparatus (officials) & 36.8 & 42.9 & 11.5 & 1.5 & 7.3 & -66.7 \\
\hline $\begin{array}{l}\text { The Armed Forces of Ukraine } \\
\text { The State Border Guard }\end{array}$ & 8.2 & 15.9 & 47.3 & 22.7 & 5.8 & 45.9 \\
\hline Service & 11.2 & 19.2 & 43.8 & 16.4 & 9.3 & 29.8 \\
\hline The National Guard of & & & & & & \\
\hline Ukraine & 12.3 & 21.6 & 42.0 & 14.3 & 9.9 & 22.4 \\
\hline The National Police & 18.6 & 31.4 & 34.6 & 6.6 & 8.8 & -8.8 \\
\hline The Security Service of & & & & & & \\
\hline Ukraine (SBU) & 19.1 & 26.7 & 33.3 & 7.7 & 13.2 & -4.8 \\
\hline The State Emergency Service & 11.5 & 16.6 & 45.5 & 17.5 & 8.9 & 34.9 \\
\hline The Prosecutor's office & 32.8 & 37.9 & 14.6 & 2.7 & 11.9 & -53.4 \\
\hline $\begin{array}{l}\text { The Courts (judicial system as } \\
\text { a whole) }\end{array}$ & 41.5 & 37.3 & 10.3 & 2.1 & 8.8 & -66.4 \\
\hline $\begin{array}{l}\text { The Local court in your area, } \\
\text { city }\end{array}$ & 32.0 & 33.8 & 14.5 & 2.8 & 16.8 & -48.5 \\
\hline $\begin{array}{l}\text { The Supreme Court } \\
\text { The Constitutional Court of }\end{array}$ & 38.5 & 30.6 & 12.8 & 2.7 & 15.4 & -53.6 \\
\hline $\begin{array}{l}\text { Ukraine } \\
\text { The Supreme Anti-Corruption }\end{array}$ & 40.2 & 28.4 & 12.6 & 2.9 & 16.0 & -53.1 \\
\hline $\begin{array}{l}\text { Court } \\
\text { The National Anti-Corruption }\end{array}$ & 41.5 & 31.2 & 10.9 & 2.3 & 14.1 & -59.5 \\
\hline $\begin{array}{l}\text { Bureau of Ukraine (NABU) } \\
\text { The National Agency for the }\end{array}$ & 36.8 & 33.4 & 13.7 & 2.6 & 13.4 & -53.9 \\
\hline $\begin{array}{l}\text { Prevention of Corruption } \\
\text { (NAPC) }\end{array}$ & 37.1 & 30.9 & 12.5 & 2.2 & 17.3 & -53.3 \\
\hline The Mass media of Ukraine & 17.5 & 29.4 & 38.4 & 6.3 & 8.4 & -2.2 \\
\hline The Russian media & 57.7 & 24.5 & 5.0 & 0.7 & 12.2 & -76.5 \\
\hline The Western media & 20.4 & 24.2 & 27.8 & 4.6 & 22.9 & -12.2 \\
\hline
\end{tabular}




\begin{tabular}{lllllll}
\hline The National Bank of Ukraine & 24.0 & 36.4 & 25.0 & 3.0 & 11.5 & -32.4 \\
The Commercial banks & 31.1 & 39.2 & 16.5 & 2.0 & 11.2 & -51.8 \\
The Trade unions & 25.5 & 24.4 & 22.9 & 3.8 & 23.4 & -23.2 \\
The Political parties & 32.3 & 39.0 & 14.8 & 3.1 & 10.7 & -53.4 \\
The NGOs & 12.7 & 20.3 & 46.0 & 7.2 & 13.8 & 20.2 \\
The Church & 10.4 & 13.7 & 43.1 & 20.8 & 12.0 & 39.8 \\
The Volunteer battalions & 15.5 & 17.3 & 38.3 & 16.3 & 12.7 & 21.8 \\
The Volunteer organizations & 8.8 & 15.5 & 45.0 & 20.1 & 10.5 & 40.8
\end{tabular}

Promoting the creation of effective and transparent local self-government is one of the most important activities of public organizations. Active public sector dialogue platforms that operate to ensure regular communication activities at the national level are:

- Forum for organizational development of civil society;

- Interactive platform "Like-minded", which implemented the project "Your Initiative".

To unite the efforts of the public sector and strengthen its common resource, it has planned to create a national online platform to discuss priority issues and identify trends in the development of the public sector of Ukraine in the coming years. There are some barriers to further democratization of society, which are due to the imperfections of both local government and technical means of interaction between local authorities and society. A preliminary study by the Civil Society Hub Network of Ukraine, created within the project "We influence the regions" within the United Nations Development Program project "the Civil Society for Democracy and Human Rights in Ukraine", implemented with the financial support of the Ministry of Foreign Affairs of Denmark and partnership with the NGO "Association for the Promotion of Self-Organization of the Population", showed that the procedures for using participation tools may contain barriers that hinder the access of residents to local self-government. Such barriers include:

- The granting the right to participate in local self-government exclusively to members of the territorial community, ie persons with the registration of residence;

- The deprivation of minors of the opportunity to participate in local self-government;

- The failure to take into account the needs and failure to create appropriate conditions for the participation of persons with disabilities in the decision-making process;

- The disregard for the gender component in participation procedures;

- The overstated subscription thresholds in support of electronic petitions, local initiatives, etc.

The issue of involving residents in local self-government in the context of the spread of COVID-19 and the introduction of quarantine requires a separate study. In particular, the questions remain:

- Unimpeded access of residents to meetings of collegial bodies of local self-government, holding general meetings, public hearings;

- Use of e-democracy tools for online interaction between government and residents, such as: epetitions; electronic appeals; electronic consultations; local initiatives, etc.

For the period of quarantine, plenary sessions of local councils, meetings of executive committees, and standing deputy commissions may be held remotely - by the videoconference or the audioconference, in addition to consideration of issues requiring secret ballot. Important anti-epidemic measures at the community level include properly informing residents about the situation regarding the spread of COVID-19 and the implemented quarantine measures. The local governments must inform residents:

- About morbidity statistics in the community, district, region, country as a whole;

- About protocols of actions in case of detection of symptoms of morbidity;

- About quarantine measures on the territory of the community;

- About the situation in hospitals;

Dragomyretska, N., Matvieienko, I., \& Samofalov, D. (2022). Systematic and educational influences of civil society on public administration communications organization in quarantine restriction COVID-19 condition. International Journal of Health Sciences, 6(1), 214-233. https://doi.org/10.53730/ijhs.v6n1.3828 
- About support programs.

An important condition for effective information is the formation of clear messages for relevant target audiences. They should be simple, concise, not overloaded with information that is easy to remember. It is also better to visualize such messages as much as possible.

The local governments can be involved in civil society organizations and opinion leaders to inform the public. The capable civil society organizations have sufficient skills to communicate effectively. They also have target audiences that they trust. The information should encourage socially responsible behavior but meet the needs of the audience.

What tools are available to local governments to properly inform the public?

Official website. For the local governments, the simplest channel for informing the public is the official website. On its website, the local government can quickly post information on countering the pandemic. The information must be presented in the most accessible format. Some local governments place articles about COVID-19 in the general news stream, forcing residents to spend time searching for this socially important information. That is why it is worth creating a separate section on the site dedicated to this issue.

Local newspapers. Unfortunately, not all Ukrainians have the opportunity to view information on the council's official website due to limited Internet access, mostly in rural areas. Low digital literacy of certain categories of the population, in particular, the elderly, also makes it impossible to convey information to them through electronic resources. Older people are accustomed to receiving information from local newspapers, so this channel of communication does not lose its relevance. Elderly people are at risk, so they should first be informed about safety measures, the algorithm of action in case of symptoms of COVID-19, the possibility of receiving social assistance. Some local communities publish their newsletters, in which they post news about the council's activities, socially useful information, and announcements (Reed et al., 2006).

Social networks. More and more Ukrainians are now using social media, so they are an excellent channel for spreading information about the pandemic. The local government can post information both on its page and in local groups and on the pages that are most popular among the population. SMS-mailings. Local governments can order mobile operators to send SMS messages to residents. This can be arranged without disclosing personal information. The messages may contain information on the importance of self-isolation, personal protective measures, help points, etc.

Involvement of elders in informing. The headman is a member of the executive committee of the local council, who works in it permanently. He represents the interests of the inhabitants of the respective village, settlement in the executive bodies of the council. The mayor usually lives in the territory he/she represents, so he/she better understands the needs of the population and the problems that need the attention of the local self-government body. In the conditions of quarantine, the headman can be engaged in informing the population. And his activities can be extremely effective if he knows his district well and maintains communication with residents. Moreover, it can also monitor compliance with quarantine restrictions.

An important function of informing the population can be performed by the bodies of self-organization of the population (BSP). The bodies of self-organization of the population are representative bodies created by residents who legally reside in the territory of a village, a settlement, a city, or their parts, to solve important tasks for the residents of the community. In a pandemic, BSPs can perform important functions, such as: cohesion of the population, dissemination of socially important information, assistance to vulnerable groups of citizens.

In the absence of Internet coverage, BSPs can be effective channels for local council communication with the public in a pandemic. The BSP management is well aware of the situation in the area for which they are responsible. Therefore, the local council should involve the BSP in developing an action plan to combat the spread of coronavirus infection.

\subsection{Methodical recommendations on the use of communication tools in quarantine}

Under quarantine conditions, recommendations for the use of communication tools relate to the procedures:

- The organization and holding of general meetings, public hearings, participation budget;

- The creation and activity of bodies of self-organization of the population and consultative and advisory 
bodies (COB);

- The access to meetings of collegial bodies (council, executive committee, deputy commissions);

- The submission and consideration of individual and collective appeals, electronic petitions, local initiatives.

When choosing a tool for interaction, the local governments need to pay attention to the level of epidemic danger in the community. In such circumstances, the introduction of e-democracy tools, as well as the adaptation of participation procedures to quarantine requirements, becomes particularly relevant. However, one of the main obstacles to the use of e-democracy tools in the community maybe the lack of Internet coverage. According to the Ministry of the Digital Transformation of Ukraine, as of the beginning of August 2020 , more than 17 thousand settlements do not have optical networks at all. About $65 \%$ of villages have not covered by high-quality high-speed fixed internet. This is about 5.75 million citizens who cannot connect to quality the Internet. Many social infrastructure institutions have not connected to fiber-optic networks, in particular: 16,040 educational institutions, 8,163 medical institutions, 3,873 institutions providing services to the population, 33,857 cultural and sports institutions.

That is, $40 \%$ of schools, $92 \%$ of libraries, $37 \%$ of hospitals do not have access to the Internet. Most of these institutions have located in villages and small towns. The Ministry of the Digital Transformation of Ukraine plans to provide $95 \%$ of the rural population with the technical ability to connect to high-speed Internet at a speed of at least $100 \mathrm{Mbps}$ in the 2024 year.

At the same time, for its part, it is expedient for the community leadership to pay priority attention to the issues of informatization of the local council body and its executive bodies. The local council may provide for the possibility of convening a general meeting at the initiative of residents using the tools of e-democracy. The local deputies have obliged to consider the decision of the general meeting at the session. To comply with the quarantine requirements, the initiators can participate in the session by videoconference. The relevant norm should be provided by the local self-government body in the order of convening general meetings/conferences of residents at the place of residence in the charter or regulations on general meetings, which are part of the charter.

It is worth noting that the local governments of the surveyed communities in response to requests for public information stated that during the quarantine period, general meetings/conferences of residents at the place of residence were not held. Modern information and communication technologies make it possible to hold meetings, conferences, and meetings online with the help of appropriate applications and programs. The list of services that can be used for public hearings online include: Zoom, the Ding Talk, Skype, the BlueJeans, and others. The residents have the right to initiate consideration in the local council of any important for the community draft decision or issue that falls within the competence of local governments.

The Law of Ukraine "On Citizens' Appeals" defines the conditions for the practical implementation of the constitutional right of citizens to appeal to the authorities. In the conditions of quarantine restrictions on the territory of the community, the local self-government body should establish a "hotline" to receive citizens' appeals by phone. It is important to introduce on the council's website special forms for electronic appeals or a separate e-mail address for citizens' appeals.

Also noteworthy is the approach to the installation of boxes for appeals in socially important institutions: in shops, at the post office, in hospitals, etc. This tool will provide feedback to residents who do not have information technology. As for electronic petitions, their submission and collection of signatures in support are exclusively online. However, if the council has duly provided for the author's participation in the electronic petition, such participation may be provided remotely under quarantine. An advisory body has been established at local self-government bodies to prepare proposals for improving the work of the local selfgovernment bodies, the participation of experts in the development of draft decisions on important issues of local importance. Such bodies include community and youth councils, specialized expert groups on specific issues, and other similar bodies. The main recommendation to ensure the work of the advisory body during the quarantine period is to hold their meetings remotely with the help of videoconferencing services with the execution of appropriate protocols on the results of work and recommendations of the local government. The advisory body is also an additional resource and information platform for disseminating information on quarantine measures among the population. In Ukraine, there are high-quality free electronic services that allow communities to implement innovative solutions without spending taxpayers' money:

Dragomyretska, N., Matvieienko, I., \& Samofalov, D. (2022). Systematic and educational influences of civil society on public administration communications organization in quarantine restriction COVID-19 condition. International Journal of Health Sciences, 6(1), 214-233. https://doi.org/10.53730/ijhs.v6n1.3828 
- EDEM platform. The web platform "Single platform of local e-democracy" aims to provide citizens with easy and convenient access to the use of several tools of e-democracy. These tools have been designed to establish a better relationship between citizens and government in solving various socially important problems. The platform allows the introduction of four electronic interaction services: a local petition; a public budget; an open city; a public consultation. Once logged in to this platform, the applicant no longer needs to enter their data to use other services. For the community to join the platform, the consent of the local government has required.

- The services for electronic surveys. The local governments and residents can conduct public opinion polls on important socio-economic issues. These surveys do not have to be conducted on the official website of the local council. An active resident, the community organization, or local council can initiate a survey of citizens through free services, such as, for example, your opinion, TakaDumka. These services have a simple registration system and are quite easy to use.

- The service for the free development of the site of the united territorial community. High-quality and safe communication between the government and the civil society in quarantine conditions is impossible without posting relevant, socially important information on the official website of the local council.

However, not all local governments of the united territorial communities have developed relevant sites. In 2018, according to the Center for Innovation Development, 86 out of 705 OTGs do not have official websites. We can assume that one of the reasons for the lack of a site is the unwillingness of local councils to allocate funds for site development, directing them to solve other socio-economic problems. Thus, the analysis allows us to state that the procedures of participation in the vast majority of the studied communities have not adapted to the needs of quarantine. Since the beginning of the epidemic and the introduction of quarantine restrictions, local governments have not made changes and clarifications to the procedures of local democracy, which are designed to ensure public participation and democratic self-government in crisis conditions; the tools of local democracy were practically not used. The communication of local selfgovernment bodies with residents was provided mainly through electronic appeals, e-petitions, application boxes, application forms on the website, hotlines on COVID-19 issues, implementation of draft participation budgets, online meetings of youth councils. In some cases, public hearings were held, which are mandatory because they considered draft urban planning documentation. Only in isolated cases do local councils post video broadcasts of meetings of their collegial bodies. However, most local governments publish draft decisions on their websites. In general, information about the tools of local democracy on the websites of local councils is weak. Only a few provided separate sections on tools for citizen participation in local selfgovernment.

The population has not been informed about the possibilities of involvement in the decision-making process during the quarantine period. In particular, the councils' websites do not contain information on how residents can influence the council's agenda, provide their consultations, and send appeals. The participation procedures also contain many barriers that reduce the availability of tools for citizens. Reasons and challenges that hindered the cooperation of civil society organizations and volunteer initiatives with the authorities, selfgovernment in the context of social cohesion. The fruitful discussions helped to identify the negative features and risks of the crisis:

- The declining levels of public confidence and the threat of a power vacuum in the regions;

- The replacement of state functions by local political groups;

- The manifestations of political regionalism, unauthorized cancellation of quarantine measures, violations, use of the situation for political struggle;

- The interregional confrontation in conditions of limited resources;

- The growing poverty in the regions, exacerbation of economic problems, social challenges;

- The information and digital inequality;

- The panic and growing social apathy;

- The increase in the number and number of marginalized groups;

- The lack of coordination of activities at the regional level in government;

- The lack of intersectoral cooperation in a crisis; 
- The lack of transparency in property decisions acquired during the crisis.

There were also some challenges to the development of cooperation between the civil society organizations, the business, the government, caused by the crisis:

- Lack of openness of information regarding resource needs.

- Ability to obtain realistic information about the problems of medical institutions in providing medical care, the real readiness of hospitals to make the necessary purchases, to offer priority services.

The volunteers pointed to cases of concealment of information about the real needs of hospitals in resources to achieve "positive indicators". Sometimes hospitals anonymously asked for help (remedies). After all, at certain stages of quarantine measures, the authorities were not always interested in disseminating problematic information. The representatives of civil society organizations sometimes saw in some initiatives of government officials to help during the epidemic it was pre-election training, measures to "mobilize the electorate." Under these conditions, the business representatives and the volunteers considered cooperation with the authorities risky, did not want to participate in PR events of candidates, did not cooperate with government officials to avoid accusations of politicization, and in the face of election competition, civil society organizations were afraid to find themselves between different political forces.

The lack of logical explanations for certain quarantine measures led to distrust on the part of the community. This situation demonstrates the lack of communication in the study of the needs and the need to find adequate regulatory steps. In a crisis, this leads to increased social tensions and problems of interaction in the community, increasing the level of socio-economic problems. Recommendations to local governments:

- Adapt the procedures for convening and holding general meetings/conferences at the place of residence, public hearings, local initiatives, the work of the body of self-organization of the population, and the advisory body to quarantine requirements, ensuring access to meetings of collegial local governments. In particular, to integrate remote forms of interaction between the government and residents into the participation procedures.

- Use e-democracy tools to interact with residents. Introduce forms for electronic appeals, petitions, and consultations on official websites. Install application boxes in the premises of the local council and social institutions: at the post office, in educational institutions, health care, social institutions.

- Ensure video broadcasting of meetings of collegial local governments. Whenever possible, provide for the online participation of initiators of e-petitions and local initiatives during their consideration by councils. Promptly publish draft decisions and decisions of collegial local governments on the official website. If possible, provide a page on the site dedicated to the tools of local democracy, which should include regulations governing participation procedures, announcements of public hearings, consultations, general meetings, meetings of the advisory body, as well as information on the tools of participation, which it is expedient to use in the conditions of quarantine.

- Introduce a page on the official website dedicated to the fight against COVID-19, where you can post upto-date and verified information on morbidity statistics, community quarantine measures, protocols for action in the presence of symptoms of the disease, hospital addresses, etc.

Recommendations to the Civil Society:

- Use tools of online interaction with the authorities: electronic appeals, local initiatives, electronic petitions, electronic consultations;

- Adhere to the rules of quarantine during participation in public hearings and general meetings, attending meetings of collegial local governments;

- Receive and disseminate information on COVID-19, which is posted on the website of the relevant state authorities and local governments.

Dragomyretska, N., Matvieienko, I., \& Samofalov, D. (2022). Systematic and educational influences of civil society on public administration communications organization in quarantine restriction COVID-19 condition. International Journal of Health Sciences, 6(1), 214-233. https://doi.org/10.53730/ijhs.v6n1.3828 
An extremely important parameter of joint work to overcome the effects of the crisis and solve problems is the transparency of actions and accountability of the authorities in procurement, allocation of resources, which were, for example, provided to businesses as charitable assistance. Transparency and openness of government prevent corruption, increase trust within communities, facilitate the effective delivery of services to meet real needs, and reduce crisis challenges. Accountability, transparency, and the study of real needs increase trust in government on the part of volunteers and businesses: they see that the government's efforts are aimed at implementing smart, competitive, and efficient procurement and distribution procedures. Such a policy can increase the activity of socially responsible businesses in providing additional resources to overcome the effects of the crisis and involve volunteers in joint activities.

\section{Conclusion}

This study examines the main aspects of the systemic influences of civil society on public administration communications. Based on analytical research local regulations governing the procedures of public participation in local self-government identified the main tools of public administration communications and norms that create barriers for residents to use the tools of local democracy. The practices of holding the general meetings, the public hearings, the budget implementation, use of electronic petitions, appeals, work of advisory bodies and self-organization bodies, organization of access to collegial bodies in conditions of quarantine restrictions due to the COVID-19 epidemic have been considered. The analysis uses the results of a survey to identify problematic aspects of communication tools to inform the public about the activities of local governments, including the direction of counteracting COVID-19. The study focuses on the interaction with the residents of the respective united territorial communities, and on the participation of public organizations in the organization of communication processes of territorial communities - to improve the quality of services to the population in quarantine measures. The peculiarities and the main aspects of the digital interaction with the residents of the territorial community and effective coverage of the government's activities with digital tools are identified. It has proposed to make more active use of e-democracy tools to interact with community members based on transparency and openness of government.

It has proved that the participation of civil society institutions in the advisory bodies of local selfgovernment significantly increases the ability of local authorities to disseminate socially important information. The capable civil society organizations have sufficient skills to communicate effectively. They also have target audiences that they trust. The communication of the civil society organizations should encourage socially responsible behavior, meet the needs of the audience.

\section{Acknowledgments}

We are grateful to two anonymous reviewers for their valuable comments on the earlier version of this paper. 


\section{References}

Ainsworth, S., \& Sened, I. (1993). The role of lobbyists: Entrepreneurs with two audiences. American Journal of Political Science, 834-866.

Albers, S., Wohlgezogen, F., \& Zajac, E. J. (2016). Strategic alliance structures: An organization design perspective. Journal of Management, 42(3), 582-614.

Berkhout, J., Hanegraaff, M., \& Braun, C. (2017). Is the EU different? Comparing the diversity of national and EU-level systems of interest organisations. West European Politics, 40(5), 1109-1131.

Bhuiyan, S. H. (2011). Modernizing Bangladesh public administration through e-governance: Benefits and challenges. Government Information Quarterly, 28(1), 54-65. https://doi.org/10.1016/j.giq.2010.04.006

Bondarenko, S., Halachenko, O., Shmorgun, L., Volokhova, I., Khomutenko, A., \& Krainov, V. (2021). The Effectiveness of Network Systems in Providing Project Maturity of Public Management. TEM

Bondarenko, S., Tkach, I., Drobotov, S., Mysyk, A., \& Plutytska, K. (2021). National resilience as a determinant of national security of Ukraine. Journal of Optimization in Industrial Engineering, 14(Special Issue), 87-93.

Bozeman, B., \& Straussman, J. D. (1990). Public management strategies: Guidelines for managerial effectiveness. Jossey-Bass.

Cherchyk, L., Korchynska, L., \& Babenko, V. (2019). Using model forests as a form of balanced forestry in Ukraine. Forestry Studies, 71(1), 69-85.

Christensen, T., Lægreid, P., \& Rykkja, L. H. (2016). Organizing for crisis management: Building governance capacity and legitimacy. Public Administration Review, 76(6), 887-897.

Daugbjerg, C., Fraussen, B., \& Halpin, D. (2018). Interest groups and policy capacity: Modes of engagement, policy goods and networks. In Policy capacity and governance (pp. 243-261). Palgrave Macmillan, Cham.

De Nicola, A., Villani, M. L., Brugnoli, M. C., \& D'Agostino, G. (2016). A methodology for modeling and measuring interdependencies of information and communications systems used for public administration and eGovernment services. International Journal of Critical Infrastructure Protection, 14, 18-27. https://doi.org/10.1016/j.ijcip.2016.06.001

Dykha, M., Cheban, Y., Bilyk, O. I., Siryk, Z. O., Khytra, O., \& Dudnyk, A. (2020). Management of corporate social activity in the organization. International Journal of Management, 11(5).

Eisinger, P. (2002). Organizational capacity and organizational effectiveness among street-level food assistance programs. Nonprofit and Voluntary Sector Quarterly, 31(1), 115-130.

Fraussen, B., \& Halpin, D. (2018). How do interest groups legitimate their policy advocacy? Reconsidering linkage and internal democracy in times of digital disruption. Public administration, 96(1), 23-35.

Hubanova, T., Shchokin, R., Hubanov, O., Antonov, V., Slobodianiuk, P., \& Podolyaka, S. (2021). Information technologies in improving crime prevention mechanisms in the border regions of southern Ukraine. Journal of Information Technology Management, 13(Special Issue: Role of ICT in Advancing Business and Management), 75-90.

Khomutenko, A., Mishchenko, A., Ripenko, A., Frum, O., Liulchak, Z., \& Hrozovskyi, R. (2019). Tools of the neuro-fuzzy model of information risk management in national security. International Journal of Engineering and Advanced Technology, 8(6), 4526-4530.

Klochan, V., Piliaiev, I., Sydorenko, T., Khomutenko, V., Solomko, A., \& Tkachuk, A. (2021). Digital Platforms as a tool for the transformation of strategic Consulting in Public Administration. Journal of Information Technology Management, 13(Special Issue: Role of ICT in Advancing Business and Management), 42-61.

Korepanov, G., Yatskevych, I., Popova, O., Shevtsiv, L., Marych, M., \& Purtskhvanidze, O. (2020). Managing the financial stability potential of crisis enterprises. International Journal of Advanced Research in Engineering and Technology (IJARET), 11(4).

Kovalenko, Y. M. (2013). Standards within the Code of Good Practice for financial activities. Current issues of economics, $148(10), 8-14$.

Kuznetsov, A., Smirnov, O., Gorbacheva, L., \& Babenko, V. (2020). Hiding data in images using a pseudorandom sequence. In CEUR Workshop Proceedings (Vol. 2608, pp. 646-660).

Leslie, E., Coffee, N., Frank, L., Owen, N., Bauman, A., \& Hugo, G. (2007). Walkability of local communities: using geographic information systems to objectively assess relevant environmental attributes. Health \& place, 13(1), 111-122. https://doi.org/10.1016/j.healthplace.2005.11.001

Lindgren, I., \& Jansson, G. (2013). Electronic services in the public sector: A conceptual framework. Government Information Quarterly, 30(2), 163-172. https://doi.org/10.1016/j.giq.2012.10.005

Dragomyretska, N., Matvieienko, I., \& Samofalov, D. (2022). Systematic and educational influences of civil society on public administration communications organization in quarantine restriction COVID-19 condition. International Journal of Health Sciences, 6(1), 214-233. https://doi.org/10.53730/ijhs.v6n1.3828 
Lozano, M., \& Vallés, J. (2007). An analysis of the implementation of an environmental management system in a local public administration.Journal of environmental management, 82(4), 495-511. https://doi.org/10.1016/j.jenvman.2006.01.013

Maloney, W. A. (2015). Organizational populations: Professionalization, maintenance and democratic delivery. In The organization ecology of interest communities (pp. 99-116). Palgrave Macmillan, London.

Manin, B. (1987). On legitimacy and political deliberation. Political theory, 15(3), 338-368.

Marquez, L. M. M. (2016). The relevance of organizational structure to NGOs' approaches to the policy process. VOLUNTAS: International Journal of Voluntary and Nonprofit Organizations, 27(1), 465-486.

Mufidah, N., Suhron, M., \& Wahyudi, R. (2021). Analysis of post-stroke anxiety (PSA) factors during the COVID19 pandemic in Indonesia. International Journal of Health \& Medical Sciences, 5(1), 1-6. https://doi.org/10.21744/ijhms.v5n1.1807

Nataliia, V., Barzylovych, A., Zabolotna, A., Boiko, M., \& Rybchych, I. (2021). Healthcare facilities management in digitalization context. International Journal of Health Sciences, 5(3), 429-440. https://doi.org/10.53730/ijhs.v5n3.1773

Pieterson, W., Ebbers, W., \& Van Dijk, J. (2007). Personalization in the public sector: An inventory of organizational and user obstacles towards personalization of electronic services in the public sector. Government Information Quarterly, 24(1), 148-164. https://doi.org/10.1016/j.giq.2005.12.001

Pugh, D. S., Hickson, D. J., Hinings, C. R., Macdonald, K. M., Turner, C., \& Lupton, T. (1963). A conceptual scheme for organizational analysis. Administrative science quarterly, 289-315.

Rajwani, T., Lawton, T., \& Phillips, N. (2015). The "Voice of Industry": Why management researchers should pay more attention to trade associations. Strategic Organization, 13(3), 224-232.

Rasmussen, A., Carroll, B. J., \& Lowery, D. (2014). Representatives of the public? Public opinion and interest group activity. European Journal of Political Research, 53(2), 250-268.

Reed, M. S., Fraser, E. D., \& Dougill, A. J. (2006). An adaptive learning process for developing and applying sustainability indicators with local communities. Ecological economics, 59(4), 406-418. https://doi.org/10.1016/j.ecolecon.2005.11.008

Rodchenko, L., Goncharenko, O., Koval, O., Tarasov, I., Nemchenko, H., \& Tkachuk, T. (2019). Optimization of innovation projects according to criteria of time and resource constraints. International Journal of Recent Technology and Engineering, 8(3), 1431-1434.

Savinova, N., Berehova, M., Yanchytska, K., Stelmah, N., Biliuk, O., \& Kasatkina-Kubyshkina, 0. (2021). ICT role during COVID-19 pandemic in lifelong learning for disabilities. International Journal of Health Sciences, 5(3), 594-604. https://doi.org/10.53730/ijhs.v5n3.2572

Savvas, I., \& Bassiliades, N. (2009). A process-oriented ontology-based knowledge management system for facilitating operational procedures in public administration. Expert Systems with Applications, 36(3), 44674478. https://doi.org/10.1016/j.eswa.2008.05.022

Schmitter, P. C., \& Streeck, W. (1999). The organization of business interests: Studying the associative action of business in advanced industrial societies (No. 99/1). MPIfG discussion paper.

Sudomyr, S., Niziaieva, V., Lutay, L., Prodanova, L., Havryliuk, O., \& Sherstyukova, K. (2020). Methods And Techniques Of Motivation Of Subjects Of Regional Economy For Innovative Improvement. International Journal of Scientific \& Technology Research, 9(03), 1196-1200.

Szczepaniuk, E. K., Szczepaniuk, H., Rokicki, T., \& Klepacki, B. (2020). Information security assessment in public administration. Computers \& Security, 90, 101709. https://doi.org/10.1016/j.cose.2019.101709

Vasilescu, R., Barna, C., Epure, M., \& Baicu, C. (2010). Developing university social responsibility: A model for the challenges of the new civil society. Procedia-Social and Behavioral Sciences, 2(2), 4177-4182. https://doi.org/10.1016/j.sbspro.2010.03.660

Verhoest, K., Peters, B. G., Bouckaert, G., \& Verschuere, B. (2004). The study of organisational autonomy: a conceptual review. Public Administration and Development: The International Journal of Management Research and Practice, 24(2), 101-118.

Wahyuni, S., Chalid, S. M. T., Pelupessy, N. U., Arifuddin, S., Idris, I., \& Usman, A. N. (2022). Comparison of the use of shock index and modified early obstetric warning score in COVID-19 obstetric emergency patients as ICU care parameters. International Journal of Health \& Medical Sciences, 5(1), 80-90. https://doi.org/10.21744/ijhms.v5n1.1844 
Widana, I.K., Sumetri, N.W., Sutapa, I.K., Suryasa, W. (2021). Anthropometric measures for better cardiovascular and musculoskeletal health. Computer Applications in Engineering Education, 29(3), 550561. https://doi.org/10.1002/cae.22202

\section{Biography of Authors}

\begin{tabular}{|c|c|}
\hline & $\begin{array}{l}\text { Natalia Dragomyretska } \\
\text { She is a Doctor of Science in Public Administration and a Professor. She works as a } \\
\text { Professor of the Department of Social Sciences and Humanities at the Odesa } \\
\text { Regional Institute of Public Administration National Academy of Public } \\
\text { Administration under the President of Ukraine (Genoese Str., 22, Odesa, Ukraine, } \\
\text { 65062). Areas of research interests: communications in public administration; } \\
\text { management of communication projects in public administration; public } \\
\text { administration systems; the influence of civil society on processes in public } \\
\text { administration. } \\
\text { Email: nataliaodessa@ukr.net }\end{array}$ \\
\hline & $\begin{array}{l}\text { Iryna Matvieienko } \\
\text { She is the Candidate of Science in Public Administration. She works as an } \\
\text { Associate Professor of the Department of Regional Policy and Public } \\
\text { Administration at the Odesa Regional Institute of Public Administration National } \\
\text { Academy of Public Administration under the President of Ukraine (Genoese Str., } \\
\text { 22, Odesa, Ukraine, 65062). Areas of research interests: civil society } \\
\text { development; interaction of public authorities with civil society institutions; } \\
\text { influences in public administration, scientific communication } \\
\text { Email: irinamatveenko19@gmail.com }\end{array}$ \\
\hline & $\begin{array}{l}\text { Dmytro Samofalov } \\
\text { He is the Candidate of Science in Medicine and a Doctoral studies of the } \\
\text { Department of Social Sciences and Humanities at the Odesa Regional Institute of } \\
\text { Public Administration National Academy of Public Administration under the } \\
\text { President of Ukraine. He works as the Director Southern Trans-regional } \\
\text { Department National Health Service of Ukraine (Odesa, Kanatna str. 83; Odesa, } \\
\text { Ukraine). Areas of research interests: communicative activity in public } \\
\text { administration of health care; health systems; models of communicative activity in } \\
\text { public administration of health care; the influence of civil society on processes in } \\
\text { public administration. } \\
\text { e-mail:dr.samofalov@gmail.com }\end{array}$ \\
\hline
\end{tabular}

Dragomyretska, N., Matvieienko, I., \& Samofalov, D. (2022). Systematic and educational influences of civil society on public administration communications organization in quarantine restriction COVID-19 condition. International Journal of Health Sciences, 6(1), 214-233. https://doi.org/10.53730/ijhs.v6n1.3828 